BNL -47165

Informal Report

THE RHODE ISLAND STATEWIDE LIGHTING PROGRAM SUMMARY REPORT

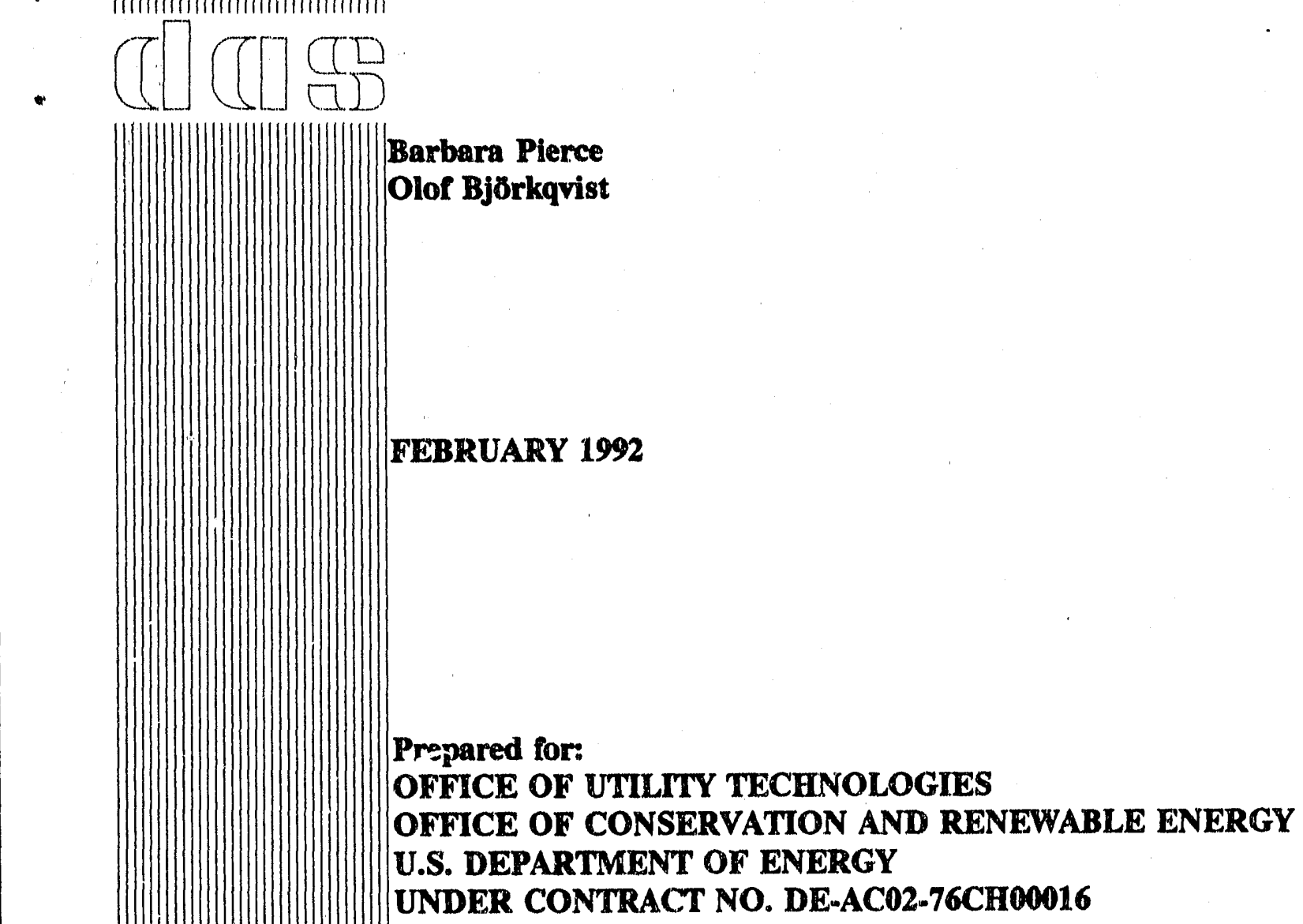

ENERGY EFFICIENCY AND CONSERVATION DIVISION DEPARTMENT OF APPLIED SCIENCE

BROOKHAVEN NATIONAL LABORATORY UPTON, LONG ISLAND, NEW YORK 11973 (1)

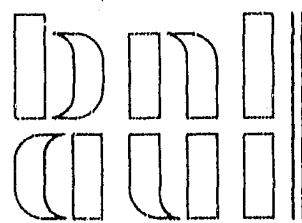


This report was prepared as an account of work sponsored by an agency of the Unfted $S$ tates Government. Nefther the Unfted $S$ tates Government nor any agency thereof, nor any of their employees, nor any of their contractors, subcontractors, or their employees makes any warranty, express or implied, or assumes any legal liability or responstbility for the accuracy, completeness, or usefulness of any information, apparatus, product or process disclosed, or represents that its use would not infringe privately owned rights. Reference herefn to any specific commercial product, process, or service by trade name, trademark manufacturer, or otherwise, does not necessarily constitute or imply its endorsement, recommendation, or favoring by the United $s$ tates Government or any agency thereof. The views and opinfons of authors expressed herein do not necessarily state or reflect those of the United States Government or any agency, contractor, or subcontractor thereof. 
BNL --471.65

DE92 009376

\title{
THE RHODE ISLAND STATEWIDE LIGHTING PROGRAM SUMMARY REPORT
}

\author{
Barbara Pierce \\ Olof Björkquist*
}

February 1992

\begin{abstract}
Prepared for
OFFICE OF UTILITY TECHNOLOGIES

OFFICE OF CONSERVATION AND RENEWABLE ENERGY

U.S. DEPARTMENT OF ENERGY

Under Contract No. DE-ACO2-76CH00016
\end{abstract}

DEPARTMENT OF APPLIED SCIENCE

BROOKHAVEN NATIONAL LABORATORY

UPTON, NEW YORK 11973

* Currently with Chalmers University of Technology, Göteborg Sweden

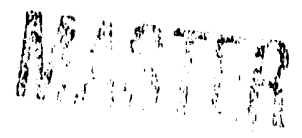




\section{Table of Contents}

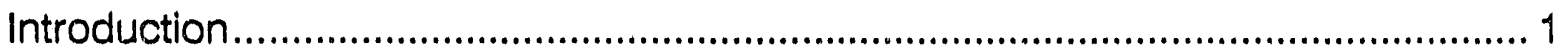

Rhode Island Statewide Lighting Program........................................................ 2

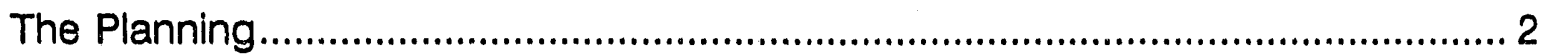

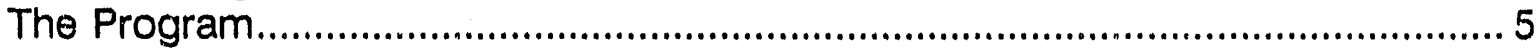

Process Evaluation and Customer Survey ........................................................... 7

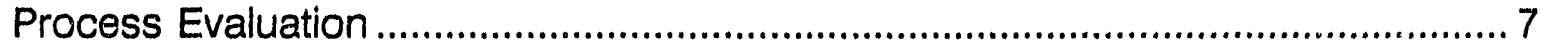

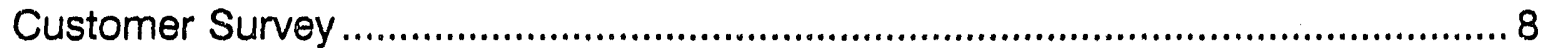

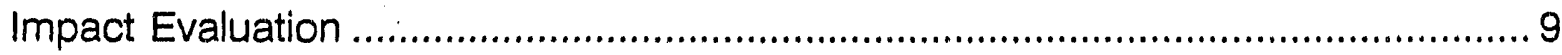

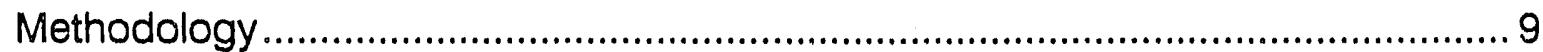

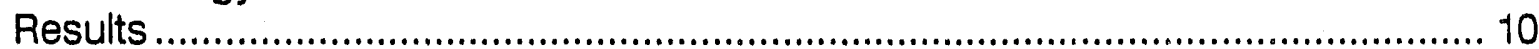

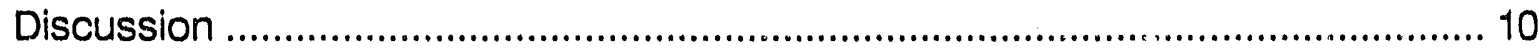

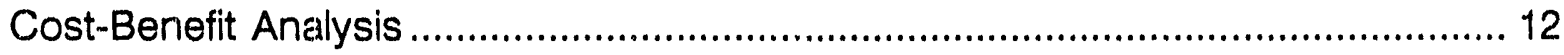

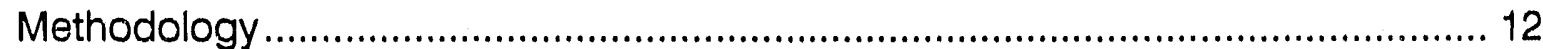

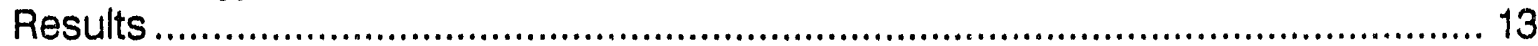

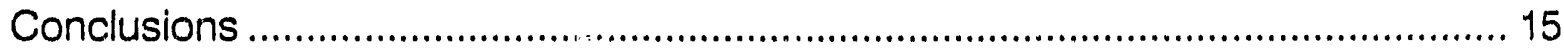

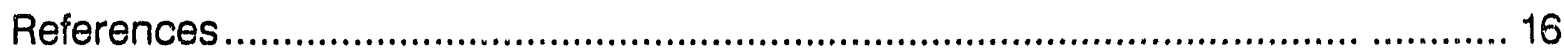

Tables

1. Rhode Isiand Commercial/Industrial Electricity Usage, 1986 .............................. 2

2. Rhode Island Commercial/Industrial Electric End Use, 1986 ............................. 3

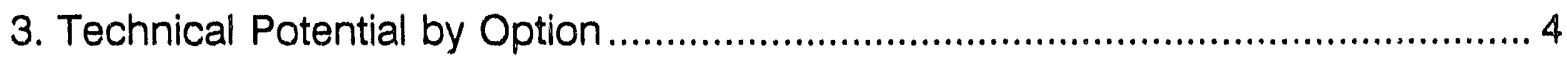

4. Benefit-Cost Ratios by Measure Packago …....................................................... 5

5. Savings by Business Type............................................................................. 10

6. Cost-Benefit Perspectives ............................................................................... 12

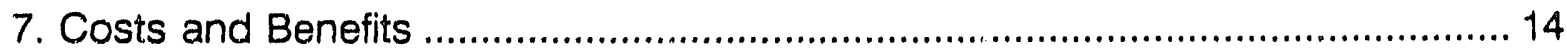




\section{PREFACE}

The U.S. Department of Energy's (DOE) Integrated Resource Planning (IRP) program sponsors research and other activities to facilitate the implementation of IRP across the country. Demand-Side Management (DSM) is the largest IRP program area.

The overall objective of the DSM program area is to provide assessments of the cost, performance, and market potential of demand-side technologies as cost-effective resources for utility planning. This includes the evaluation of energy efficiency and load management technologies and programs in terms of costs, performance, energy savings, and load shaping potential, as well as consumer acceptance.

For several years DOE, through Brookhaven National Laboratory, has supported efforts in Rhode Island to develop a statewide conservation program. This report describes the development and preliminary evaluation of Rhode Island's Statewide Lighting Program. 


\section{ACKNOWLEDGEMENTS}

The authors would like to thank all those involved in the Rhode Island project for their cooperation and assistance during the preparation of this report. Special thanks to Mary Kilmarx (Rhode Island Public Utilities Commission), Meredith Miller (New England Electric System), Carol White (Eastern Utilities Associates), and Vince Graziano (RISE). 
This report summarizes the implementation and initial evaluation of the nation's first statewide conservation and load management program, the Rhode Island Statewide Lighting Program (RISLP). Rhode Island's program is unique because it is a voluntary collaborative effort and because three utilities use a single delivery mechanism for their programs.

In 1986 New England governors adopted $A$ Plan for Meeting New England's Electricit;' Needs. This plan calls for accelerating utilities' implementation of conservation and load management to meet the region's capacity needs. In response, the Rhode Island Least-Cost Planning Committee (RILCPC) ${ }^{1}$ was formed. Participants are the Rhode Island Governor's Office of Entergy Assistance, the Rhode Island Public Utilities Commission, the state's three major utilities (Narragansett Electric Company, Blackstone Valley Electric Company, and Newport Electric Corporation), and Rhode Islanders Saving Energy, Inc. (RISE), a non-profit energy services organization supported by the electric and gas utilities in the state.

The Committee determined that significant conservation opportunities exist to reduce peak demand in the commercial and industrial sectors, and identified seven conservation technologies for evaluation. The technical potential for energy and demanci savings of these seven technologies was assessed and quantified (Xenergy, October 1988). Evaluation of audit data showed that lighting accounts for 33 percent of Rhode Island's commercial/industrial electric end use. Lighting measures, including high-efficiency technologies, reduced lighting levels as appropriate, and load control measures, have the technical potential to reduce statewide commercial/industrial lighting use by 42 percent, summer peak due to lighting by nearly 45 percent and winter peak by more than 55 percent.

Costs and benefits of various program designs were examined, a Statewide Least-Cost Plan was developed, and the initial statewide program, lighting assessment and direct installation, was designed (Xenergy, December 1988). The Statewide Lighting Program was initiated in the beginning of 1989. Early in the program, the Committee decided to evaluate the program in terms of program effectiveness and customer satisfaction, and to perform a preliminary impact evaluation.

The U.S. Department of Energy and Brookhaven National Laboratory have supported Rhode Island's efforts in both the design phase and in the initial evaluation. The purpose of this report is to provide a summary of the Statewide Lighting Program and its evaluation to date. The next section describes the Lighting Program, including both the measures and the delivery mechanism. The following sections summarize results from the process and impact evaluations and present a brief cost/benefit analysis.

1 The Rhode Island Least Cost Planning Committee has since been renamed the Rhode Island Demand-Side Planning Committee. 


\section{The Planning}

The first step in planning the statewide program was to develop baseline energy-use data for the commersial and industrial sector in Rhode Island. An existing database from audits performed on 954 facilities was supplemented by an additional 30 audits, stratified by building type and size, to make the database fully representative of the state as a whole.

Using utility billing data, individual audits were weighted to reflect the number of actual facilities represented by the audited facility. The resultant database provided statewide enduse and demand-side management information including energy use, equipment types and efficiencies, fuel choices and applicability of technology options. Table 1 shows electricity use for 1986. Commercial/industrial electricity sales were 3,415,667 MWh, about 60 percent of total sales in 1986. The sector accounted for approximately 75 percent of the summer peak load.

The database provides information on end-use sales and end-use loads. The load shapes were reconciled to Narragansett Electric load research data (representing about 70 percent of the state) and scaled to the statewide level. Table 2 shows total end-use sales. In this table, chiller motors are included in the air conditioning category, while all other motors, including air handling, ventilation, and processing equipment, motors, are included in the motors enduse category. Lighting represents one-third of the electricity usage in the sector and contributes significantly to both summer and winter peaks.

Table 1

Rhode Island Commercial/Industrial Electricity Usage, 1986

\begin{tabular}{lrrr}
\hline \multicolumn{1}{c}{ Sector } & $\begin{array}{c}\text { Annual } \\
\text { MWh }\end{array}$ & $\begin{array}{c}\text { Summer } \\
\text { Peak (MW) }\end{array}$ & $\begin{array}{c}\text { Winter } \\
\text { Peak (MW) }\end{array}$ \\
\hline Office & & & 86.8 \\
Restaurant & 492,301 & 107.4 & 23.4 \\
Retail & 151,886 & 32.2 & 53.5 \\
Food Store & 289,410 & 85.5 & 18.7 \\
Schools & 168,721 & 26.7 & 38.9 \\
Health & 232,301 & 37.9 & 21.1 \\
Hotel/Motel & 153,373 & 31.6 & 9.7 \\
Personal Services & 63,009 & 11.3 & 33.4 \\
Large Area Services & 131,688 & 42.4 & 21.3 \\
Wholesale & 121,609 & 27.8 & 12.8 \\
Mechanical Industrial & 83,505 & 18.5 & 175.8 \\
Thermal Industrial & 987,444 & 210.9 & 114.0 \\
\multicolumn{1}{c}{ TOTAL } & 540,420 & 116.1 & 609.4 \\
\hline
\end{tabular}

Source: XENERGY 
Table 2

Rhode Island Commercial/Industrial Electric End Use, 1986

\begin{tabular}{|c|c|c|c|c|c|c|}
\hline \multirow[b]{2}{*}{ End Use } & \multicolumn{2}{|c|}{ Annual Sales } & \multicolumn{2}{|c|}{$\begin{array}{l}2 \text { PM Summer } \\
\text { Peak Day }\end{array}$} & \multicolumn{2}{|c|}{$\begin{array}{l}6 \text { PM Winter } \\
\text { Peak Day }\end{array}$} \\
\hline & MWh & $\%$ & MW & $\%$ & MW & $\%$ \\
\hline Lighting & $1,115,980$ & 33 & 251.2 & 34 & 266.2 & 44 \\
\hline Air conditioning & 352,613 & 10 & 183.9 & 24 & ' - & 0 \\
\hline Motors & 633,861 & 19 & 128.0 & 17 & 117.6 & 19 \\
\hline Heating & 166,449 & 5 & - & 0 & 25.3 & 4 \\
\hline All Others* & $1,146,764$ & 33 & 185.2 & 25 & 200.3 & 33 \\
\hline TOTAL & $3,415,667$ & 100 & 748.3 & 100 & 609.4 & 100 \\
\hline
\end{tabular}

Source: XENERGY

The second step in the planning process was to determine the potential for savings. The RILCPC identified six conservation technologies which could have a significant impact on the critical summer weekday afternoon peak, and one to address the winter evening peak. These are:

- high efficiency lighting and ballasts, as well as conversion to HID fixtures;

- automatic dimming equipment for office perimeter lighting;

- redesign of lighting to reduce light levels to minimum effective levels;

- high efficiency motor replacement;

- high efficiency air conditioning equipment;

- peak shaving opportunities on occasional utility request, such as shutoff of perimeter lighting, activation of standby generators, and moderate increases in summer thermostat settings; and

- early evening control of lighting and heating use in commercial facilities to reduce winter evering peak.

For each of these technologies, individual measures were defined and evaluated for potential energy savings. For example, the measures evaluated for the first category, high efficiency lighting, were:

- high efficiency fluorescents

- high efficiency incandescents

- compact fluorescents

- incandescent to HIDs

- high efficiency ballasts

- electronic ballasts. 
Table 3

Technical Potential by Option

\begin{tabular}{|c|c|c|c|}
\hline Technology Option & $\begin{array}{l}\text { Aunual } \\
\text { Energy } \\
\text { Savings } \\
\text { (MWh) } \\
\end{array}$ & $\begin{array}{c}\text { Summer } \\
\text { Demand } \\
\text { Savings } \\
\text { (MW) }\end{array}$ & $\begin{array}{l}\text { Winter } \\
\text { Demand } \\
\text { Savings } \\
\text { (MW) }\end{array}$ \\
\hline High Efficiency Lighting Technologies & 362,677 & 107.4 & 95.0 \\
\hline Autc matic Dimming Equipment for Office Perimeter Lighting & 9,420 & 5.8 & 0.0 \\
\hline Redissign of Lighting to Meet Appropriate Light Levels & 59,450 & 17.7 & 16.0 \\
\hline Enetgy Efficient Motors & 54,397 & 11.1 & 10.1 \\
\hline Enel:gy Efficient Air Conditioning Equipment & 54,512 & 35.5 & 0.0 \\
\hline Dispratchable Load Management on Request (Summer) & 6,205 & 31.0 & 0.0 \\
\hline Early Evening Control Strategies (Winter) & 63,533 & 0.0 & 45.7 \\
\hline Total Savings & 610,194 & 208.5 & 166.8 \\
\hline Percent Savings & 17.9 & 27.9 & 27.4 \\
\hline
\end{tabular}

Source: XENERGY

The evaluation included consideration of the fraction of end-use equipment that is appropriate for conversion and a feasibility factor, to prevent overlap problems and infeasible circumstances for installation. For example, because of the overlap of lamp and ballast savings in the same fixtures, the savings fractions were adjusted to prevent double-counting.

The seven technologies have the technical potential to reduce Rhode Island electrical usage by 610,194 MWH per year. This represents 17.9 percent of the electricity use in the commercial/industrial sector. Summer and winter demand can each be reduced by nearly 30 percent. These results are shown in Table 3.

The third step in planning a least-cost program for Rhode Island was to examine the costs and benefits to the utilities of alternative program designs. Two levels of payback reduction, two years and free, were analyzed on the premise that as measure paybacks decrease, measure implementation by customers increase. Net impacts ( $\mathrm{kW}$ and $\mathrm{kWh})$, net benefits $(\$$, demand and energy impacts times utility avoided costs), and program costs (\$) were estimated for each measure to determine the cost-effectiveness of the buydown programs. Weighted average avoided costs and discount rates for the three utilities were used in the calculations.

Individual measures were combined into packages and benefit-cost ratios calculated. Table 4 shows the results. All of the two-year packages have benefit-cost ratios greater than one. Only cooling fails the benefit-cost test in the zero year buydown. Load management packages are the most cost-effective. 
Table 4

Benefit-Cost Ratios by Measure Package

\begin{tabular}{lcc}
\hline \multicolumn{1}{c}{ Measure Package } & $\begin{array}{c}\text { Benefit Cost Ratio } \\
\text { for } \\
\text { Two-Year Buydown }\end{array}$ & $\begin{array}{c}\text { Benefit Cost Ratio } \\
\text { for } \\
\text { Zero-Year Buydown }\end{array}$ \\
\hline Fluorescent Lighting & 1.81 & 1.15 \\
Incandescent Lighting & 4.06 & 1.77 \\
Motors & 2.29 & 1.28 \\
Cooling & 1.18 & 0.89 \\
Load Reduction on Request & 7.20 & 3.62 \\
Evening Control & 4.57 & 2.30 \\
\hline
\end{tabular}

Source: XENERGY

Using these results as well as individual utility evaluations, the RILCPC selected lighting as the end-use to target for the initial statewide program. A delivery mechanism was agreed upon and ways to coordinate utility programs with a unified statewide approach were developed.

\section{The Program}

The Statewide Lighting Program consists of three components: a free lighting analysis; the installation of free efficient lamps ( 2 and 4-foot fluorescents and compact fluorescents); and rebates for additional measures. These services are provided on behalf of the utilities by Rhode Islanders Saving Energy, Inc. (RISE), a non-profit energy services organization. The three participating utilities are Narragansett Electric, Blackstone Valley Electric (BVE), and Newport Electric. Each utility determines customer eligibility requirements and which measures qualify for rebates, as well as the level of rebates.

Some unique features of Rhode Island's program are:

- The program was planned and is being overseen by a collaborative organization of utility, state policy and regulatory staff which form the RILCPC. The group differs from similar regional collaborative efforts in that it does not involve any outside organizations and it is voluntary;

- The lighting program represents the RILCPC's first attempt at implementing conservation measures on a statewide basis through an independent delivery mechanism, rather than having each utility provide its own program to its customers; and

- The lighting program also represents the first direct installation program provided on a statewide basis. 
The unique design of the program allows each utility to meet its individual needs and retain its identity, while ensuring that all customers in the state, not just those of the larger utilities, are provided with services.

The Utilities

Narragansett Electric is a wholly-owned subsidiary of the New England Electric System. It accounts for approximately 70 percent of the electric sales in Rhode Island and has about $28,000 \mathrm{commercial} /$ industrial customers in the state.

For Narragansett, customers with a peak load of $100 \mathrm{~kW}$ or less (over 90 percent of commercial/industrial customers) are eligible for the Statewide Program; larger customers are offered separate programs.

Blackstone Valley Electric Company (BVE) is a wholly owned subsidiary of Eastern Utilities and serves approximately 81,000 customers in northern Rhode Island. BVE accounts for about 20 percent of electricity sales in Rhode Island. All of BVE's commercial/industrial customers $(7,000)$ are eligible for the Statewide Program.

Newport Electric, which recently became a subsidiary of Eastern Utilities, serves a population of approximately 70,000. Newport commercial/industrial customers with a peak load of $500 \mathrm{~kW}$ or less are eligible for the Statewide Program.

\section{Program Delivery}

RISE provides the program services for the Statewide Lighting Program. RISE performs the audits, presents the results to the customer, informs the customer of additional programs that may be available from the utility, installs the free measures, and may contract for the installation of further measures if the customer desires.

Each participating customer receives at least two visits from RISE, one to perform the audit and one to present the results. Installations of free or additional measures occur during additional visits, along with inspections of installations.

RISE invoices each utility for its costs, which include audit and installation costs, and measure costs for BVE and Newport. Narragansett purchases measures for its own customers directly.

Early in the program, the RILCPC decided to conduct an evaluation of the program to assess program effectiveness and customer satisfaction, and to provide a preliminary assessment of energy savings impacts. The following section presents results of the process evaluation and customer survey; the next section discusses the impact evaluation. 
The process evaluation was performed by Freeman Research Resources as subcontractor to Applied Management Sciences. The full report can be found in Volume I: Process Evaluation and Survey Results: Evaluation of the Rhode Island Lighting Program.

\section{Process Evaluation}

The process evaluation was conducted during October and November of 1989. It consisted of three components:

- on-site observation of the delivery of program services to customers;

- interviews withi individuals involved in the program; and

- review of documents and forms used in the program.

The investigator attended an audit with a program auditor, and observed a lighting installation in progress at a second site. Informal interviews with the participants took place during these visits. In addition, interviews were conducted with 13 individuals involved in either the planning, implementation, or monitoring of the program.

Results indicate that those who deliver program services and those who sponsor and oversee the program are overwhelmingly pleased with the Statewide Lighting Program, as well as the processes by which the program was conceived and is being implemented. Participation in the Rhode Island Least Cost Planning Committee as a program design and monitoring forum has been deemed successful by virtually all of those involved.

Use of a single organization for program delivery was also found to be appropriate and successful; the use of RISE as the delivery mechanism received unanimous approval. The quality of the RISE audit staff was highly praised.

In general program sponsors seemed quite pleased with the progress that has been made in the program, although some expressed disappointment that more customers were not choosing to participate in the rebate programs, especially in the small to medium customer categories. It may be that additional incentives are needeo to reach this customer segment, or that the link between the free lamps and the major measures is not clear. The customer is not required to make any investment in order to get the free items, and each utility has its own version of the rebate portion, which makes it more difficult for the auditor to understand the various options and to explain their advantages to the customer.

Each utility has a different context and set of objectives within which its version of the program must operate and be offered to customers; each utility also makes frequent alterations to its program offerings. Further, each utility needs to maintain its own image. In spite of these complexities, the concept of a centrally administered statewide implementation system for conservation services appears to work well. The utility sponsors largely felt satisfied with the efforts being made by RISE staff to promote the fact that it is the individual utilitics that are providing the services of the program to customers. 
Suggested improvements in the administrative and structural features of the program include: better information transfer from the auditor to the installation team; simpler calculated retates, especially those that involve a $\mathrm{kWh}$ component in addition to a $\mathrm{kW}$ component; a more formal reporting system by RISE for summary statistics on activity levels and costs; improved and simplified audit software, specific to lighting measures, and possibly the use of hand-held computers.

\section{Customer Survey}

The customer satisfaction evaluation consisted of a telephone survey of 247 participating commercial and industrial customers, administered by Applied Management Sciences' Computer Assisted Telephone Interviewing center. Results were weighted to reflect the total population of participants ( 788 at the time of the survey). The survey consisted of 34 questions which had been provided by the Least-Cost Planning Committee.

Participating customers expressed high levels of satisfaction with the program. Seventy-one percent rated the program excellent and 27 percent rated it good.

When asked which if any items or measures they were dissatisfied with, approximately 80 percent said none. Six to 13 percent expressed dissatisfaction with some items, 6 percent with high efficiency ballasts and 12 and 13 percent with compact and high efficiency fluorescents, respectively. Customers were asked if the installed measures were still in use. Only 2.5 percent indicated that any were not; most of these had not yet actually installed the item.

Customers were also asked whether they felt that the quality of light was better, worse, or the same as before, Forty-two persent indicated better quality, 19 percent worse, 35 percent saw no change, and 13 percent were not sure.

Several of the survey questions explored the extent of program influence on customer behavior. Participants reported that the program caused them to take action where none was planned (48\%), to do more than had originally been intended $(16 \%)$, to act sooner than intended $(13 \%)$, or to make different selections than originally intended $(12 \%)$. Thus, the program had a positive influence on the behavior of 90 percent of the sample of participants. 
The Phase I impact evaluation, described here, was designed to measure the energy savings being achieved by the Statewide Program and to compare the measured savings to the engineering estimates. This preliminary impact evaluation is based on an analysis of changes in summer electricity use between 1988 and 1989, for customers who had been retrofitted with the program's measures on or before May 1, 1989.

The impact evaluation was performed by Applied Management Sciences and is fully described in Volun II: Program Impacts Analysis: Evaluation of the Rhode Island Lighting Program.

\section{Methodology}

The methodology used in the analysis is a before-after/test-control (BATC) means comparison. The differences in mean electric energy usage for inatched groups of participants and non-participants between 1988 and 1989 were compared. For each utility, groups of participants and non-participants were stratified by business type and summer season $\mathrm{kWh}$.

Two data sources were used. Billing data from each utility contained information on both participants and non-participants. Audit data for participants were provided by RISE. Preliminary processing on the billing files resulted in the deletion of out-of-scope accounts and deletion of accounts for which more than one month of data was missing for either year. The audit data file was then merged against the utility billing files to create the participant files for the impact analysis.

Throughout the evaluation out-of-scope records were deleted. In addition, eight large industrial customers (each with summer consumptiorı at least an order of magnitude greater than that for other customers) were deleted. The final analysis included 278 participants; 2400 non-participants were included in the control group.

Both the participant and non-participant groups were stratified by business type and total summer $\mathrm{kWh}$ for 1988. Six business types, based on SIC codes, were used. These are office, restaurant, retail, food store, other (including health and hotel/motel), and industrial. One utility's billing file (used to define the controi group) did not contain SIC codes. Each account was manually assigned to a business type, based on the account name and address.

Energy consumption cell means for summer 1988 and summer 1989 were calculated for both participant and nonparticipant groups. The participants' 1988 summer $\mathrm{kWh}$ is multiplied by a scaling factor to estimate what their consumption in 1989 would have been if they had not participated in the program. This scaling factor is the ratio of the non-participants' 1989 summer $\mathrm{kWh}$ to their 1988 summer $\mathrm{kWh}$. It is a measure of the change in summer $\mathrm{kWh}$ that occurred without program participation. The participants' actual $\mathrm{kWh}$ for the summer of 198 ? is subtracted from the estimated 1989 summer $\mathrm{kWh}$ to yield the net savings. 
Engineering estimates were taken from the audit file. These annual estimates had been calculated for each lamp installed at each location, using hours of usage provided by the owner. To compare the measured savings to the engineering estimates, the annual engineering estimate, from the audit data file were divided by three to give a four month estimate which could be compared directly to the measured savings.

\section{Results}

The impact analysis found that the net savings estimate was approximately 20 percent of the engineering estimate. Overall net savings totaled $138,412 \mathrm{kWh}$. While offices, restaurants, food stores, and industrial establishments showed positive net savings, retail stores and other comrıercial establishments had negative net savings. These results are shown in Table 5.

Table 5 also shows the mean net $\mathrm{kW}$ savings by business type, along with the assumed hours of operation used to calculate them.

\section{Discussion}

There are several limitations which should be considered in interproting the results. First, because the evaluation occurred early in the program, the number of participants and corresponding data were limited. Second, the evaluation was not designed at the time of program inception which resulted in considerable effort to "back-fit" the design structure on derived data. Third, the evaluation does not include sophisticated features to separately address changes due to non-program factors. Finally, the assumption that four months of summer savings would be comparable to one-third of annual savings may not be appropriate, especially for lighting. A later evaluation by one of the participating utilities using a full year of billing data showed savings of 59 percent of * igineering estimates, which is more in line with other impact evaluations of lighting programs.

\begin{tabular}{|c|c|c|c|c|c|}
\hline \multicolumn{6}{|c|}{$\begin{array}{c}\text { Table } 5 \\
\text { Savings by Business Type } \\
\end{array}$} \\
\hline Business Type & $\begin{array}{l}\text { Number of } \\
\text { Participants }\end{array}$ & $\begin{array}{c}\text { Net Savings } \\
\mathrm{kWh}\end{array}$ & $\begin{array}{c}\text { Mean } \\
\text { Net Savings } \\
\text { kWh }\end{array}$ & $\begin{array}{c}\text { Mean } \\
\text { Net kW } \\
\text { Savings } \\
\end{array}$ & $\begin{array}{c}\text { Assumed } \\
\text { Hours of } \\
\text { Operation* }\end{array}$ \\
\hline Office & 95 & 150,133 & 1,580 & 1.80 & $11 \mathrm{hrs} . /$ day $\times 5$ days $/ \mathrm{wk}$ \\
\hline Restaurant & 13 & 12,773 & 982 & 0.73 & 1.2 hrs./day $\times 7$ days/wk \\
\hline Retail & 59 & $-25,448$ & -431 & -0.32 & 12 hrs./day $\times 7$ days/wk \\
\hline Food Store & 11 & 4,293 & 390 & 0.29 & 12 hrs./day $\times 7$ days/wk \\
\hline Other Commercial & 63 & $-26,741$ & -424 & -0.31 & $12 \mathrm{hrs} . /$ day $\times 7$ days $/$ wk \\
\hline Industrial & 37 & 23,402 & 632 & 0.49 & 16 hrs./day $\times 5$ days $/$ wk \\
\hline Total & 278 & 138,412 & & & \\
\hline \multicolumn{6}{|c|}{ Multiplied by 4 weeks/month and 4 months. } \\
\hline
\end{tabular}


The unexpectedly low savings estimates prompted a detailed examination of the data used in the evaluation. It was discovered that the billing data provided by one utility did not include the necessary meter constants. The meter constant is required to calculate actual consumption. While the correct meter constants were provided for the participants, there was no assurance that the same problem did not occur with the non-participant billing data.

Multi-metered locations proved to be a significant and unforseen problem for at least one utility. Data for these locations required additional effort to verify that the correct meter information was used. A data flag was used to eliminate records where the estimated savings exceeded pre-installation usage. Individual records were examined when possible, but time and resource constraints did not permit examination of all records. It is likely that discrepancies due to multi-metered locations remained.

The lessons learned during the evaluation will serve to improve program design and evaluation activities in the future. Recommendations for future evaluations using billing data include: thoroughly understand the structure and contents of the billing data system and the DSM program database; educate billing data providers about how the data will be used; develop data flags to allow identification of out-of-scope records; verify that the correct meter at multi-metered locations is used; and allow sufficient time for close examination of some individual records. 
To supplement the process and impact evaluations described above, BNL performed a costbenefit analysis of the initial phase of the Statewide Program. The cost-effectiveness of demand-side management programs is an important consideration for DOE, as well as others, in evaluating the various options for achieving improved energy efficiency. In addition, the experience of performing such an analysis may help to identify data needs and issues in evaluation.

The analysis presented in this chapter is for the Statewide Program as a whole; results are not presented for the individual utilities. This analysis is not meant to substitute for the rigorous analyses performed by individual utilities for their own purposes.

The participating utilities and RISE were extremely helpful in providing the data necessary to perform this analysis.

\section{Methodology}

Present value costs and benefits were calculated for three perspectives: participant, utility, and total resource/society. Costs and benefits included in each perspective are shown below.

Because this analysis was not done for a specific utility (with rate and incentive implications) or for non-participants, the issue of free riders was not considered. Utility lost income and profitability issues are likewise not included.

The time frame used is five years. Most of the measures installed in the initial phases of the program were the free measures, that is, the bulbs and lamps which have an expected lifetime of 4 to 6 years. To extend the time frame further would require estimates of replacement rates and costs. In addition, the impact evaluation covers only four months, and results from an extended cost-benefit analysis based on a limited irnpact evaluation would not be reliable.

\begin{tabular}{|c|c|c|}
\hline & $\begin{array}{c}\text { Table } 6 \\
\text { Cost-Benefit Perspectives }\end{array}$ & \\
\hline Perspective & Costs & Benefits \\
\hline Participant & Direct investment & Electricity bill savings \\
\hline Utility & $\begin{array}{l}\text { Free measure product and installation } \\
\text { Rebates } \\
\text { Advertising } \\
\text { Audit costs } \\
\text { Overhead }^{1}\end{array}$ & $\begin{array}{l}\text { Avoided costs } \\
\text { Environmental benefits }\end{array}$ \\
\hline Society & All of the above & $\begin{array}{l}\text { Avoided costs } \\
\text { Environmental benefits }\end{array}$ \\
\hline
\end{tabular}


Six categories of costs were used in the analysis. RISE includes three categories of costs in billing the utilities - product cost, labor fees, and audit fees. The product cost and labor fees were combined and called free measure costs. Because Narragansett supplies the measures for its segment of the program, Narragansett product costs were derived separately and included in the total. Free measure costs thus include the cost of the products - the bulbs and tubes - and the labor to install them.

Rebate costs were supplied by each utility, although they constituted a very small part of total costs in this early part of the Statewide Program. Advertising and overhead costs were also provided by each utility. Overhead costs include utility payroll and overhead expenses.

Participant direct investment costs are calculated for the rebated measures and assumed to be 85 percent of the total cost. Again, these are very small because there were very few rebates given in the initial months of the program.

Participant electricity bill savings are calculated based $n=$ an average rate supplied by one of the utilities. No demand component is included because for the most part the small commercial and industrial customers do not have a demand component in their rates.

Utility avoided costs were provided by each utility, and weighted to account for relative shares of electricity sales. These costs represent current approaches to developing avoided costs, and thus include costs associated with transmission and distribution and adjustments for losses and reserves.

The real discount rate used in the analysis for utilities was calculated from nominal rates provided by the utilities using an assumed inflation rate of 4 percent, and weighted by utility. The rates for the participant and society perspectives were estimated.

Rhode Island currently has no requirement for including environmental externalities in utility planning. Therefore a simple 15 percent adder was selected to represent the environmental benefits of reduced electricity production.

\section{Results}

The five year costs and benefits are shown in Table 7, along with the benefit-cost ratio for each perspective.

It should be emphasized that the time frame used in this analysis (January through April for costs and May through September for benefits) represents the initial or start-up phase of the program. It can be expected that costs per participant and per $\mathrm{kWh}$ saved will go down as the program matures. 


\begin{tabular}{|c|c|c|c|}
\hline & $\begin{array}{c}\text { Table } 7 \\
\text { Costs and Ben }\end{array}$ & & \\
\hline & $\begin{array}{c}\text { Participant } \\
\text { perspective } \\
\end{array}$ & $\begin{array}{c}\text { Utility } \\
\text { perspective }\end{array}$ & $\begin{array}{c}\text { Society } \\
\text { perspective }\end{array}$ \\
\hline Time horizon (years) & 5 & 5 & 5 \\
\hline Rate of discount (real) & $6.00 \%$ & $4.07 \%$ & $3.00 \%$ \\
\hline Environmental externality & $0.00 \%$ & $15.00 \%$ & $15.00 \%$ \\
\hline Total saved energy (MWh) & 3,097 & 3,097 & 3,097 \\
\hline Annual saved demand $(\mathrm{kW})$ & 251 & 251 & 251 \\
\hline Total benefit (1989\$) & $\$ 228,663$ & $\$ 247,61.5$ & $\$ 255,765$ \\
\hline Total cost $(1989 \$)$ & $\$ 18,475$ & $\$ 374,624$ & $\$ 397,534$ \\
\hline \multicolumn{4}{|l|}{ Benefit cost ratios } \\
\hline - Excluding externalities & 12.4 & 0.7 & 0.6 \\
\hline - Including externalities & & 0.8 & 0.7 \\
\hline
\end{tabular}




\section{Conclusions}

The Rhode Island Statewide Lighting Program is a unique attempt to improve the efficiency of electricity use in the commercial/industrial sector on a statewide basis. The cooperative nature of program design and implementation has strengthened communication among the participants. The process evaluation showed that both the participants and the customers are satisfied with the program. The program has had a significant effect on customer behavior.

While the savings estimates from the preliminary impact analysis are low and probably do not reflect the actual savings achieved by the program, several lessons have been learned which will improve future program design and evaluation activities. A key consideration in the future will be to develop evaluation plans at the same time a program is designed. This will guarantee that the necessary data are available to perform a valid evaluation. Secondarily, several issues specific to working with billing data have been identified and solutions developed.

Finally, the utility participants have identified a number of benefits of Rhode Island's unique joint effort. The Planning Committee provides a forum for utilities and regulatory agencies to openly discuss State energy policy objectives. It has allowed participants to develop an appreciation for the level of effort required in program planning, implementation, and evaluation, and to learn from the expertise of each other. The utility participants aiso feel that there are economies of scale in joint efforts, and that programs such as Rhode Island's Statewide Lighting Program have the potential to reduce customer confusion about conservation and load management serviceis. 
Applied Management Sciences, Inc. and Freeman Research Resources. Volume I: Process Evaluation and Survey Results: Evaluation of the Rhode Island Lighting Program, AMS 7535, Aspen Systems Corporation, Silver Spring, MD., August 1990.

Applied Management Sciences Division. Volume II: Program Impacts Analysis: Evaluation of the Rhode Island Lighting Program, AMS 7535, Aspen Systems Corporation, Silver Spring, MD., September 1991.

Massachusetts Electric. 1990 DSM Performance Measurement Report, submitted to Department of Public Utilities, Commonwealth of Massachusetts, June 1991.

Miller, Meredith and Luisa Freeman. "The Rhode Island Lighting Program: Using Market Research to Assess the Implementation Process," presented at New England Market Research Symposium, Hanover, New Hampshire, September 17, 1990.

White, Carol and Meredith Miller. "Billing Data Analysis Lessons," presented at 5th National Demand-Side Management Conference, Boston Mass., July 30 - August 1, 1991.

Xenergy Inc. A Statewide, Least-Cost Plan for Rhode Island, Xenergy Inc., Burlington, Mass., December 1988.

Xenergy Inc. Technology Options and Potential for Energy Savings for Rhode Island Least-Cost Planning Project, Xenergy Inc., Burlington, Mass., October 1988. 

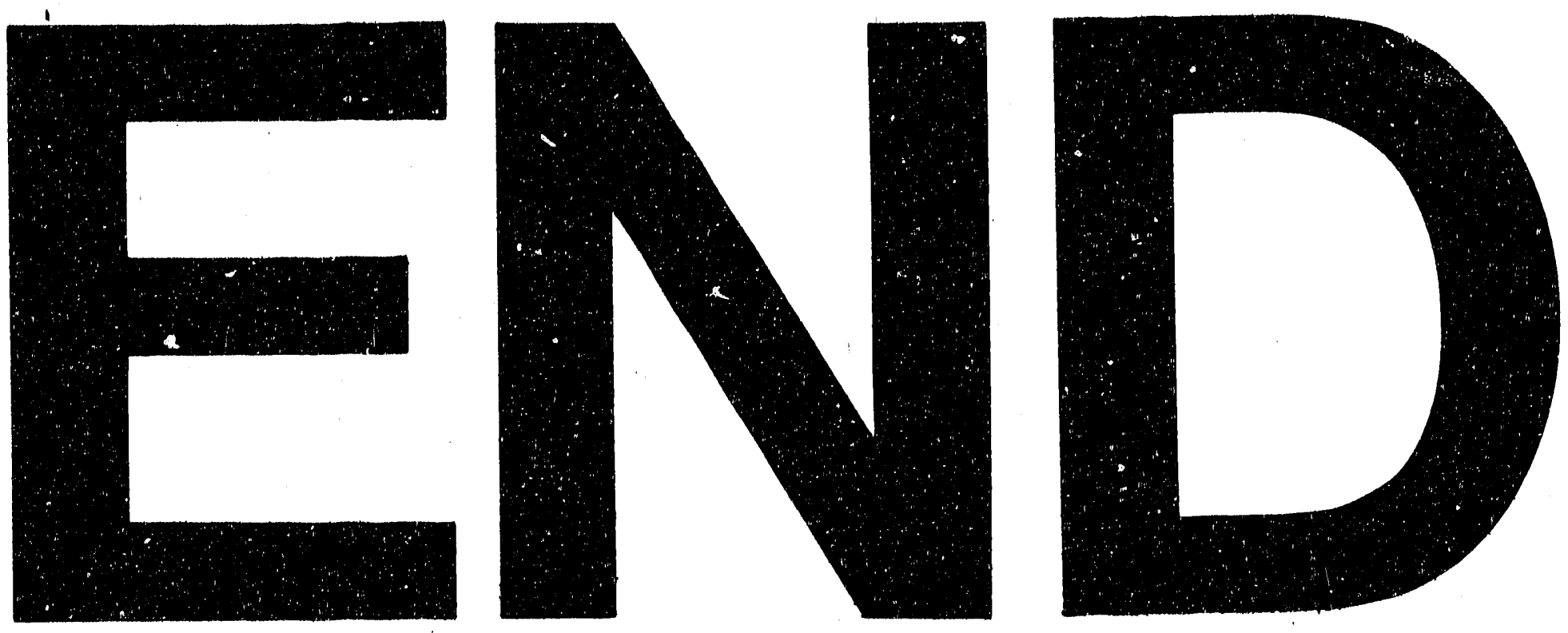

$=-1$
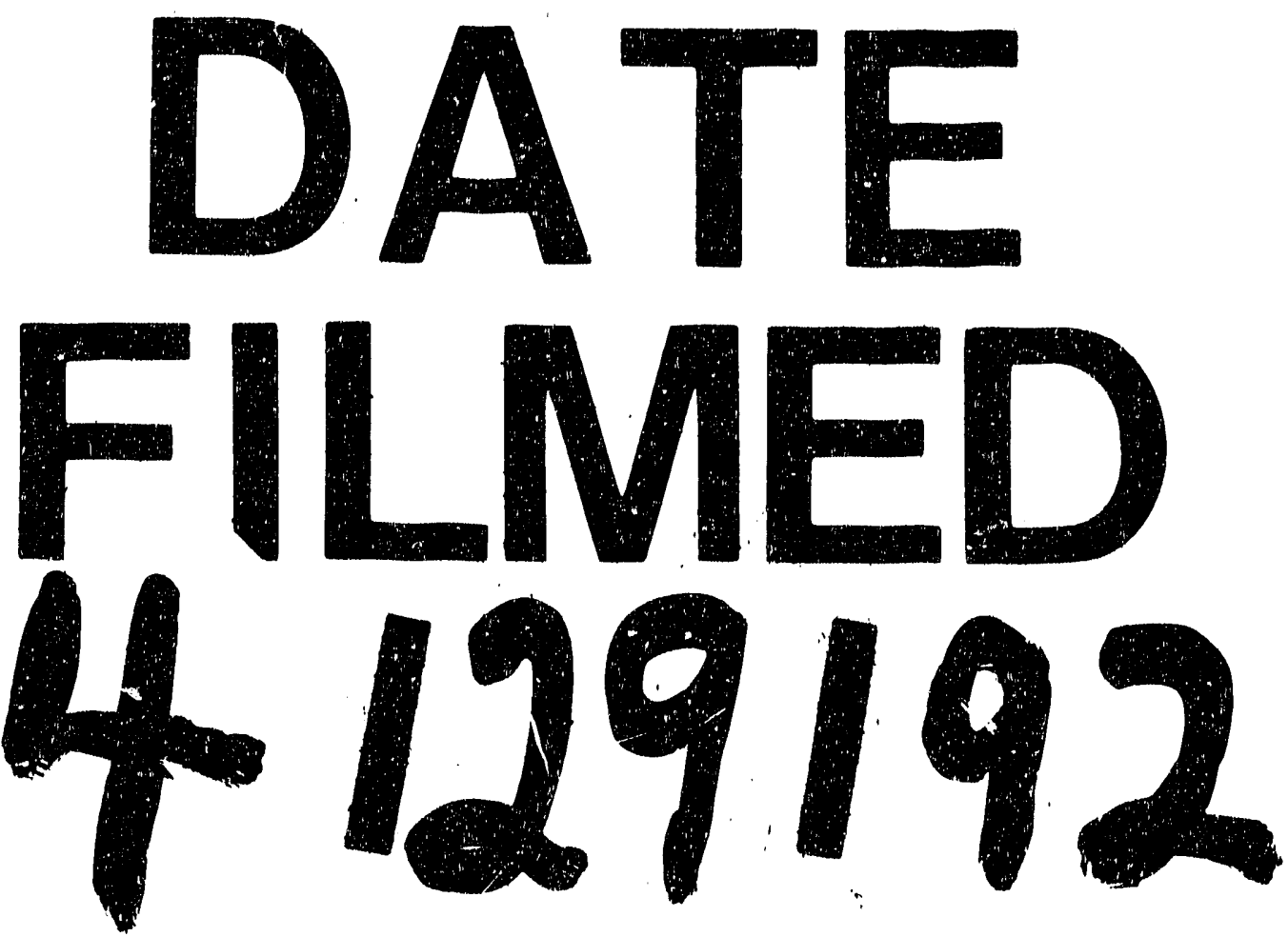


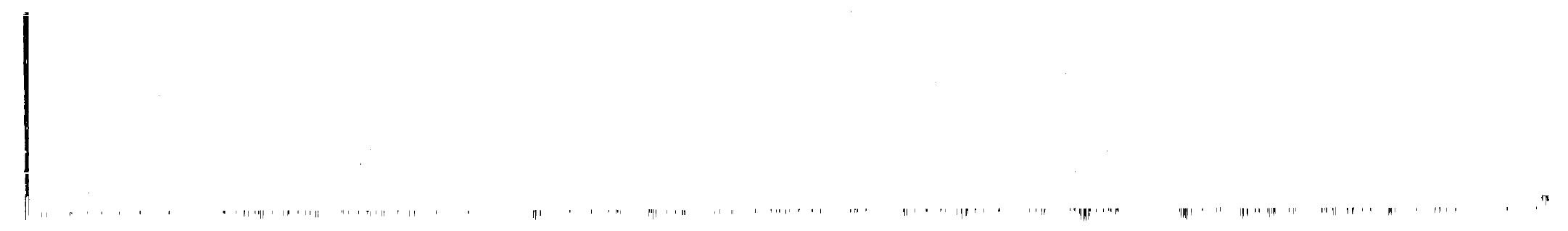

